\title{
The impact of iodised salt or iodine supplements on iodine status during pregnancy, lactation and infancy
}

\author{
Michael B Zimmermann* \\ Laboratory for Human Nutrition, Swiss Federal Institute of Technology Zürich, ETH Zentrum, Schmelzbergstrasse 7, \\ LFV E19, CH-8092 Zürich, Switzerland
}

\begin{abstract}
Objectives: Monitoring of iodine status during pregnancy, lactation and infancy is difficult as there are no established reference criteria for urinary iodine concentration (UI) for these groups; so it is uncertain whether iodized salt programs meet the needs of these life stages.

Design and Subjects: The method used in this paper was: 1) to estimate the median UI concentration that reflects adequate iodine intake during these life stages; and 2) to use these estimates in a review of the literature to assess whether salt iodisation can control iodine deficiency in pregnant and lactating women, and their infants.

Results: For pregnancy, recommended mean daily iodine intakes of 220-250 $\mu \mathrm{g}$ were estimated to correspond to a median UI concentration of about $150 \mu \mathrm{g} \mathrm{l}^{-1}$, and larger surveys from the iodine sufficient countries have reported a median UI in pregnant women $\geq 140 \mu \mathrm{g} \mathrm{l}^{-1}$. Iodine supplementation in pregnant women who are mild-tomoderately iodine deficient is beneficial, but there is no clear affect on maternal or newborn thyroid hormone levels. In countries where the iodine intake is sufficient, most mothers have median breast milk iodine concentration (BMIC) greater than the concentration (100-120 $\mu \mathrm{g}^{-1}$ ) required to meet an infant's needs. The median UI concentration during infancy that indicates optimal iodine nutrition is estimated to be $\geq 100 \mu \mathrm{g} \mathrm{l}^{-1}$. In iodine-sufficient countries, the median UI concentration in infants ranges from 90-170 $\mu \mathrm{g} \mathrm{l}^{-1}$, suggesting adequate iodine intake in infancy.

Conclusions: These findings suggest pregnant and lactating women and their infants in countries with successful sustained iodised salt programs have adequate iodine status.
\end{abstract}

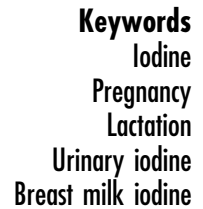

\section{Introduction}

Iodine deficiency (ID) causes a broad range of adverse effects on health resulting from the inadequate production of thyroid hormone that are collectively termed ID disorders (IDD). An ID during pregnancy increases the risk of spontaneous abortion, low birth weight and infant mortality $^{1-5}$ as well as raising the risk of neuromotor, behavioural and cognitive impairment in the offspring ${ }^{6-8}$. Even a mild-to-moderate ID during pregnancy can cause transient hypothyroidism, can increase the thyroid volume in mothers and their infants, and may impair cognition $^{9-13}$. During infancy, an adequate amount of iodine is required for normal mental development ${ }^{12,13}$; a meta-analysis estimated that ID in a population lowered mean IQ scores by 13.5 points ${ }^{14}$. It is for these reasons that IDD control programmes should focus on pregnancy, lactation and infancy, the stages in life when iodine requirements are at their greatest.

However, the assessment of iodine status during these life stages is challenging. The main indicator in a population of a response to salt iodisation is the median urinary iodine (UI) concentration ${ }^{15}$, but there are no established reference values for the median UI concentration during pregnancy, lactation or infancy. A median concentration of iodine in the range of $100-199 \mu \mathrm{gl}^{-1}$ in the urine of school-aged children and in non-pregnant, non-lactating adults indicates an adequate iodine intake and optimal iodine nutrition ${ }^{15}$. This range has not been validated to reflect an adequate iodine status in pregnant and lactating women or in infants and, as discussed below, if applied to these target groups is likely to underestimate the true degree of ID. Most large systematic surveys of ID have been done in school-aged children or in the general adult population, and have only rarely included pregnant or lactating women, or infants. Many of the studies on pregnant women and infants have comprised only small numbers, and sampling has rarely been representative, making it difficult to draw firm conclusions. Despite this, there is some concern over whether iodised salt programmes meet the needs of these life stages. Therefore, the general objectives of this paper are to: 
1. Review the current recommended iodine intake in pregnancy, lactation and infancy.

2. Estimate the median UI concentration that reflects an adequate iodine intake during these life stages.

3. Use the estimates of an adequate UI concentration to assess whether current approaches to salt iodisation and iodine supplementation can control ID in pregnant and lactating women, and in their infants.

\section{Methods used to estimate the requirement for iodine}

There are three main ways of estimating how much iodine is required to meet daily needs.

\section{Iodine turnover}

The daily uptake and turnover of radioactive iodine can be used to estimate the requirement for iodine, provided that the subjects being tested have an adequate iodine status and are euthyroid ${ }^{16-18}$.

\section{Iodine balance}

Several studies have estimated iodine requirements from balance experiments ${ }^{19-23}$, but they have serious limitations. This is mainly because many ingested substances contain unrecognised iodine, so that a strict control of iodine intake is difficult to achieve. Because of the need to consider the iodine content of the thyroid gland, in addition to iodine intake and excretion, even during prolonged balance studies, an equilibrium may not clearly be established ${ }^{19}$.

\section{Urinary iodine concentration and thyroid size}

Since $>90 \%$ of dietary iodine eventually appears in the urine ${ }^{23,24}$, the concentration of iodine in urine is an excellent indicator of recent iodine intake. An increase in thyroid size is the earliest clinical sign of impaired iodine nutrition and reflects an adaptation to the threat of hypothyroidism.

\section{Definitions of recommendations for iodine intake}

The United States Institute of Medicine (IOM) has proposed several categories of reference intake ${ }^{25}$. The recommended dietary allowance (RDA) is the average daily iodine intake sufficient to meet the iodine requirement of about $97 \%$ of healthy individuals in a particular life stage. It is intended to be used as a goal for the daily intake of iodine by individuals.

The RDA is based on the estimated average requirement (EAR) which is the daily iodine intake, defined by specific criteria, that meets the requirement of half of the healthy individuals in a particular life stage. It assumes a normal distribution of intake. The RDA is derived from the EAR after taking into consideration the estimated variability in individual requirements. The EAR is not meant to be used to define the intake of individuals, but can be used for groups.

The adequate intake (AI) can be given if there is not enough scientific evidence to calculate an EAR. For example, the AI of iodine during infancy is based on observed mean iodine intakes by healthy, full-term, breast-fed infants in areas where iodine intake is known to be sufficient. The AI is expected to meet or exceed the amount of iodine needed in almost all individuals in the specified population group, and can be used as a goal for individual intake.

According to the WHO, UNICEF and the ICCIDD, the recommended iodine intake is the amount estimated to cover the needs of nearly all healthy individuals in the specified life stage ${ }^{15}$.

\section{Iodine requirements}

\section{Non-pregnant women}

Studies of iodine turnover, radioiodine uptake by the thyroid and balance studies of euthyroid adults have suggested that the average daily requirement for iodine is 91-96 $\mu \mathrm{g}$ per day ${ }^{16,17,20}$. There is no evidence to suggest that the average iodine requirement of adults varies with age $^{25}$. Thus, the IOM have set the EAR of iodine by women $\geq 14$ years at $95 \mu \mathrm{g}$ per day ${ }^{25}$. The RDA, which is defined as the EAR plus twice the coefficient of variation of intake of the population and then rounded to the nearest $50 \mu \mathrm{g}$, is $150 \mu$ g day $^{-1}$ for females $\geq 14$ years $^{25}$. This amount agrees with the WHO, UNICEF and the ICCIDD recommended daily iodine intake for non-pregnant women of $150 \mu \mathrm{g}$ per day $^{15}$. These amounts are summarised in Table 1.

\section{Pregnant women}

The iodine requirement during pregnancy increases for three reasons: (1) an increase in the production of thyroxine $\left(\mathrm{T}_{4}\right)$ by the mother to maintain her euthyroid state and transfer thyroid hormone to the foetus; (2) the transfer of iodine to the foetus, particularly in late gestation and (3) an increase in renal iodine clearance (RIC) by the mother ${ }^{26,27}$. The amount of iodine accumulated by the infant at the time of delivery has been used to estimate the daily foetal iodine uptake. The average iodine content of the thyroid gland of a newborn is $50-100 \mu \mathrm{g}$, with $>95 \%$ daily iodine turnover ${ }^{28,29}$. Balance studies have found that the average iodine retention of full-term infants is $6.7 \mu \mathrm{g} \mathrm{kg}^{-1}$ per day ${ }^{30}$, so the mean retention of iodine by a healthy foetus with a weight of $3 \mathrm{~kg}$ would be about $22 \mu \mathrm{g} \mathrm{day}^{-1}$. An estimated daily iodine uptake by the thyroid gland of about $75 \mu \mathrm{g} \mathrm{day}^{-1}$ by the foetus and an EAR of $95 \mu \mathrm{g} \mathrm{day}^{-1}$ for non-pregnant women would yield an EAR of $170 \mu \mathrm{g} \mathrm{day}^{-1}$ during pregnancy. The balance studies of Delange et al. suggest an EAR of $22+95=117 \mu \mathrm{g}$ per day $^{30}$. Dworkin et al. found that five pregnant women were in iodine balance when 
Table 1 The intake of iodine by women of child-bearing age, pregnant and lactating women, and infants recommended by the WHO, UNICEF and the ICCIDD ${ }^{15}$ and by the United States Institute of Medicine 25 .

\begin{tabular}{|c|c|c|c|}
\hline Authority & Life stage & Basis of amount & $\mu \mathrm{g}_{\text {day }^{-1}}$ \\
\hline WHO, UNICEF, ICCIDD & $\begin{array}{l}\text { Children } 0-59 \text { months } \\
\text { Women }>12 \text { years } \\
\text { Pregnant and lactating women }\end{array}$ & & $\begin{array}{r}90 \\
150 \\
200\end{array}$ \\
\hline United States Institute of Medicine & $\begin{array}{l}\text { Infants } 0-6 \text { months } \\
\text { Infants } 7-12 \text { months } \\
\text { Women } \geq 14 \text { years } \\
\text { Women } \geq 14 \text { years } \\
\text { Pregnancy } \\
\text { Pregnancy } \\
\text { Lactation } \\
\text { Lactation }\end{array}$ & $\begin{array}{l}\text { Al } \\
\text { Al } \\
\text { EAR } \\
\text { RDA } \\
\text { EAR } \\
\text { RDA } \\
\text { EAR } \\
\text { RDA }\end{array}$ & $\begin{array}{r}110 \\
130 \\
95 \\
150 \\
160 \\
220 \\
209 \\
290\end{array}$ \\
\hline
\end{tabular}

$\mathrm{Al}$, adequate intake; EAR, estimated average requirement; RDA, recommended daily allowance.

consuming about $160 \mu \mathrm{g} \mathrm{day}^{-1}$, with no significant differences pre- and post-partum ${ }^{19}$. Several authors have measured the thyroid volume during pregnancy and correlated it with the UI concentration and the effects of iodine supplements. In the studies of Romano et al. ${ }^{31}$ and Pedersen et al. ${ }^{9}$, total daily iodine intakes of about 200 and $250-280 \mu \mathrm{g}$, respectively, during pregnancy prevented an increase in thyroid volume, while in the study of Glinoer ${ }^{10}$, a total daily iodine intake of about $150 \mu \mathrm{g}$ was insufficient to prevent an increase in thyroid size. On the basis of these data, the IOM set the EAR at $160 \mu \mathrm{g} \mathrm{day}^{-1}$ for pregnancy in women $\geq 14$ years, and set the RDA, estimated to be $140 \%$ of the EAR rounded to the nearest $10 \mu \mathrm{g}$, at $220 \mu \mathrm{g}$ per day $^{25}$. The WHO, UNICEF and the ICCIDD recommend a daily iodine intake of $200 \mu \mathrm{g} \mathrm{day}^{-1}$ for pregnant women, a value $10 \%$ lower than the RDA ${ }^{15}$ (see Table 1 ).

\section{Lactating women}

If a lactating woman produces an average of 0.78 and 0.601 of milk per day during the first and second 6 months of infancy, respectively ${ }^{25}$, and if the mean breast milk iodine concentration (BMIC) is $146 \mu \mathrm{gl}^{-1}$ in iodinesufficient women in the USA, the average daily loss of iodine in breast milk has been estimated to be about $114 \mu \mathrm{g}$ per day ${ }^{25}$. When this amount is added to the EAR of non-pregnant women of $95 \mu \mathrm{g} \mathrm{day}^{-1}$, the EAR for lactating women $\geq 14$ years is estimated by the IOM to be $209 \mu \mathrm{g}$ per day ${ }^{25}$. The RDA is thus $140 \%$ of the EAR rounded to the nearest $10 \mu \mathrm{g}$, which is $290 \mu \mathrm{g} \mathrm{day}^{-1}$ of iodine. The WHO, UNICEF and the ICCIDD recommend a daily iodine intake of $200 \mu$ g day $^{-1}$ by lactating women ${ }^{15}$, which is similar to the EAR but 30\% lower than the RDA (see Table 1).

\section{Infancy (O-12 montbs)}

Since no functional criteria are available that reflect iodine intake in infants, recommended intakes are based on the mean iodine intake of healthy full-term infants fed on human milk. The IOM based their recommendation on the median BMIC of women in the United States of America (USA) in the early $1980 \mathrm{~s}$, which was $146 \mu \mathrm{g}$ per ${ }^{25}$. Since the iodine intake of the population of the USA was relatively high at this time ${ }^{32}$, this BMIC is at the upper end of the range of 78-167 $\mu \mathrm{gl}^{-1}$ reported for women in iodinesufficient countries (see later discussion). Based on estimates of the mean daily volume of breast milk, the mean amount of iodine secreted in human milk is estimated to be about $115 \mu \mathrm{g}$ per day ${ }^{25}$. Balance studies of full-term infants given $20 \mu \mathrm{g} \mathrm{kg}^{-1} \mathrm{day}^{-1}$ of iodine found that the total amount excreted was $12.7 \mu \mathrm{g} \mathrm{kg}^{-1} \mathrm{day}^{-1}$ and the amount retained was $7.3 \mu \mathrm{g} \mathrm{kg}^{-1}$ per day ${ }^{30}$. If the reference body weight of an infant aged 6 months is $7 \mathrm{~kg}^{25}$, the daily amount of iodine excreted by an infant in positive balance is $90 \mu \mathrm{g}$. Considering these data, the recommended AI of iodine for infants aged 0-6 and 6-12 months has been set at 110 and $130 \mu \mathrm{g} \mathrm{day}^{-1}$, respectively, by the $\mathrm{IOM}^{25}$. The WHO, UNICEF and the ICCIDD recommend a daily iodine intake of $90 \mu \mathrm{g} \mathrm{day}^{-1}$ for infants ${ }^{15}$, which is $20-30 \%$ lower than the RDA (see Table 1).

\section{Iodine intakes in pregnancy and the effects of iodine supplementation}

\section{Pregnancy}

The WHO, UNICEF and the ICCIDD recommend using the median UI concentration to assess the iodine nutrition of populations ${ }^{15}$. The daily iodine intake can be extrapolated from the UI if it is assumed that girls aged 7-15 years produce $0.9 \mathrm{ml}$ urine $\mathrm{h}^{-1}$ per $\mathrm{kg}^{33}$, and adult women produce about 1.51 per day ${ }^{34}$. If it is assumed that the mean bioavailability of iodine is $92 \%$, the recommended daily iodine intakes during pregnancy of $200^{15}$ and $220 \mu \mathrm{g}^{25}$ would correspond to a UI concentration of $120-135 \mu \mathrm{gl}^{-1}$ in pregnancy. As pregnancy may occur in adolescence, particularly in developing countries, a 15-year-old girl weighing some $50 \mathrm{~kg}$ with a daily iodine intake of 200 or $220 \mu \mathrm{g}$ would have a UI concentration of $170-190 \mu \mathrm{gl}^{-1}$.

However, during pregnancy, it may be less valid to estimate the iodine intake from the UI concentration due to an increase in the glomerular filtration rate $\mathrm{r}^{35}$ and, 
possibly, an increase in RIC ${ }^{36}$. If the RIC increases during pregnancy, the daily iodine intake extrapolated from the UI concentration in pregnancy would be lower than that in non-pregnancy. However, the evidence for an increase in RIC and a consequent decrease in the plasma inorganic iodide (PII) concentration during pregnancy is equivocal. The study of Aboul-Khair et al. suggested an increase in RIC using an indirect method ${ }^{36}$, while Liberman et al. directly measured the PII concentration and reported no significant difference in PII or UI concentration both preand post-partum in 16 women living in a population with a high iodine intake ${ }^{37}$. The iodine balance study of Dworkin et al. also found no differences in the UI concentration both pre- and post-partum ${ }^{19}$. Owing to the lack of clear data, it is uncertain whether pregnancy per se significantly increases the UI concentration. Therefore, in this review, the above extrapolations from UI concentration to daily iodine intake proposed by the $\mathrm{IOM}^{25}$ were considered valid, and the recommended daily intakes of $200-220 \mu \mathrm{g}$ of iodine $e^{15,25}$ were considered to correspond to a median UI concentration of $125-135 \mu \mathrm{gl}^{-1}$ in adult pregnant women, although a higher median of about 170$180 \mu \mathrm{gl}^{-1}$ may be more appropriate if pregnancy occurs in early adolescence. Although more data are clearly needed, a median UI concentration in pregnant women $\geq 140 \mu \mathrm{gl}^{-1}$ has been used in this review as an indicator of adequate iodine intake.

Table 2 compares the UI concentration of pregnant women with the general population in countries with iodine intakes ranging from excessive to deficient. Most studies analysed spot urine samples and few had an adequate power to classify iodine status based on a median UI concentration from such samples ${ }^{38}$. Few studies have compared the UI concentration of pregnant women with a control group of non-pregnant women. As shown in Table 2, the UI concentration in pregnant women and in the general population generally appear to be similar. However, this may be due to a preponderance of studies in areas where there is low or marginal iodine sufficiency, as several studies in iodine-sufficient countries have found a significantly higher median UI concentration in pregnant women $^{39-43}$. All of the large studies in iodine-sufficient countries have reported a median UI concentration in pregnant women of $\geq 140 \mu \mathrm{gl}^{-1}$. This includes countries where all salt is iodised (Switzerland and Iran), and countries where dietary iodine comes from either iodised salt or from other food sources (USA, UK, Sri Lanka and Sweden). If a median UI concentration $\geq 140 \mu \mathrm{gl} l^{-1}$ in pregnant women is taken to represent a mean iodine intake $\geq 200 \mu \mathrm{g} \mathrm{day}^{-1}$, then it appears that the iodine status of pregnant women is adequate in countries where the general population is adequately covered either wholly or partially by iodised salt programmes.

Studies of thyroid size in pregnant women support these data. As shown in Table 3, in countries affected by mild or moderate ID (Ireland, Germany, Belgium, Italy and Denmark), the thyroid volume increases 15-31\% during pregnancy, while in iodine-sufficient countries (Finland, USA and The Netherlands), there is little or no increase in thyroid volume during pregnancy ${ }^{44}$. This suggests that iodine status is adequate in pregnant women in iodine-sufficient countries with two important caveats. First, the question remains unanswered of whether RIC changes enough during pregnancy to confound the usual estimation of iodine intake based on the median UI concentration. Second, iodine-containing supplements taken during the prenatal period may have led to an increased median UI concentration in pregnant women living in countries with an iodised salt programme ${ }^{45}$.

\section{Iodine supplements during pregnancy and their impact on iodine status}

In Europe, $13-50 \%$ of women receive iodine-containing supplements during pregnancy ${ }^{45}$. In a study of 511 pregnant Swiss women in 1999, although 70\% received a prenatal supplement, only $13 \%$ received a supplement containing iodine; the median UI concentration in the women taking iodine-containing supplements was 194 vs. $130 \mu \mathrm{gl}^{-1}$ in non-supplemented women ${ }^{42}$. After a $33 \%$ increase in the concentration of iodine in salt, a study of 276 pregnant Swiss women in 2004 reported a median UI concentration of $254 \mu \mathrm{g} \mathrm{l}^{-1}$; there was no significant difference in the median UI concentration of women taking iodine-containing supplements compared with those who were not ${ }^{43}$.

In a recent study of 109 pregnant German women, the median UI concentration was $181 \mu \mathrm{gg}^{-1}$ creatinine (cr.); $58 \%$ were taking iodine-containing supplements and had a significantly higher UI concentration $\left(204 \mu \mathrm{g} \mathrm{g}^{-1} \mathrm{cr}\right.$.) than women who were not $\left(148 \mu \mathrm{g} \mathrm{g}^{-1} \mathrm{cr} \text {. }\right)^{46}$.

In earlier studies of women in Denmark ${ }^{47}$ and Germany ${ }^{48}$, the median UI concentration was significantly higher in pregnant women supplemented with iodine than women not supplemented: 58 vs. $35 \mu \mathrm{g} \mathrm{day}^{-1}$ in Denmark and 85 vs. $59 \mu \mathrm{g} \mathrm{day}^{-1}$ in Germany.

In Hungary, about $50 \%$ of pregnant women receive a supplement containing iodine. In those women taking supplements containing $\geq 150 \mu \mathrm{g}$ iodine per day, the median UI concentration was $115-130 \mu \mathrm{g} \mathrm{g}^{-1} \mathrm{cr}$., compared with $57-68 \mu \mathrm{gg}^{-1} \mathrm{cr}$. in women who were not supplemented $^{49}$.

In a cross-sectional study in Denmark, the use of iodine supplements of $150 \mu \mathrm{g} \mathrm{day}^{-1}$ and thyroid function were assessed in 144 pregnant women and their newborns ${ }^{50}$. At full term, the median UI concentration of supplemented mothers was $60 \mu \mathrm{gl}^{-1}$ compared with $35 \mu \mathrm{gl}^{-1}$ in unsupplemented mothers. In the supplement group, the concentration of thyroglobulin ( $\mathrm{Tg}$ ) in both maternal and cord blood was significantly lower, 
Table 2 Urinary iodine concentration ${ }^{1-3}$ of pregnant women in longitudinal $(L)$ and cross-sectional $(C)$ studies and, if available, in the general population or in non-pregnant controls. The urinary iodine concentration in the post-partum period is shown if a longitudinal study continued after delivery.

\begin{tabular}{|c|c|c|c|c|c|c|}
\hline Reference & $\begin{array}{l}\text { lodine status } \\
\text { Country }\end{array}$ & $n$ & $\mathrm{~L}$ or $\mathrm{C}$ & $\begin{array}{l}\text { Trimester of pregnancy } \\
\text { or time post-partum (PP) }\end{array}$ & $\begin{array}{l}\text { Urinary iodine } \\
\text { concentration }\end{array}$ & $\begin{array}{l}\text { General population } \\
\text { or controls }\end{array}$ \\
\hline & lodine excess & & & & & \\
\hline \multirow[t]{5}{*}{37} & Chile & 19 & L & 1 & $594^{1}$ & \\
\hline & & 19 & L & 2 & $469^{1}$ & \\
\hline & & 19 & L & 3 & $786^{1}$ & \\
\hline & & 19 & L & 3 months PP & $459^{1}$ & \\
\hline & lodine sufficient & & & & & \\
\hline 67 & Iran & 403 & C & $1,2,3$ & $186-338^{2}$ & $193-312^{2}$ \\
\hline \multirow[t]{3}{*}{40} & Sri Lanka & - & C & 1 & $181^{2}$ & $147^{2}$ \\
\hline & & & C & 2 & $136^{2}$ & \\
\hline & & & $\mathrm{C}$ & 3 & $154^{2}$ & \\
\hline \multirow[t]{3}{*}{68} & Sweden & 51 & L & 1 & $180^{1}$ & \\
\hline & & 51 & L & 2 & $170^{1}$ & \\
\hline & & 51 & L & 3 & $145^{1}$ & \\
\hline 42 & Switzerland & 511 & $\mathrm{C}$ & 2,3 & $138^{2}$ & $115^{2}$ \\
\hline 69 & Switzerland & 153 & C & $1,2,3$ & $205^{3}$ & $91^{3}$ \\
\hline 43 & Switzerland & 281 & C & $1,2,3$ & $254^{2}$ & $129^{2}$ \\
\hline \multirow[t]{3}{*}{40} & UK & - & $\mathrm{C}$ & 1 & $125^{2}$ & $73^{2}$ \\
\hline & & & C & 2 & $170^{2}$ & \\
\hline & & & C & 3 & $147^{2}$ & \\
\hline 70 & USA & 290 & $\mathrm{C}$ & $1,2,3$ & $148^{1}$ & $130^{1}$ \\
\hline \multirow[t]{7}{*}{11,41} & Singapore & 253 & $\mathrm{C}$ & 3 & $124^{2}$ & $98^{2}$ \\
\hline & & 230 & $\mathrm{~L}$ & 1 & $107^{2}$ & \\
\hline & & & & 2 & $116^{2}$ & \\
\hline & & & & 3 & $124^{2}$ & \\
\hline & & & & 6 weeks PP & $105^{2}$ & \\
\hline & & & & 3 months PP & $104^{2}$ & \\
\hline & lodine deficient & & & & & \\
\hline \multirow[t]{5}{*}{71} & Belgium & 334 & C & 1,2 & $50^{2}$ & $50-75^{1}$ \\
\hline & & 334 & C & 2,3 & $45^{2}$ & \\
\hline & & 136 & C & 1 & $56^{2}$ & \\
\hline & & 133 & C & 2 & $50^{2}$ & \\
\hline & & 49 & $\mathrm{C}$ & 3 & $50^{2}$ & \\
\hline \multirow[t]{5}{*}{9} & Denmark & 26 & L & 2 & $51^{2}$ & $50^{1}$ \\
\hline & & 26 & L & 3 & $40^{2}$ & \\
\hline & & 26 & L & 1 week PP & $30^{2}$ & \\
\hline & & 26 & $\mathrm{~L}$ & 26 weeks PP & $50^{2}$ & \\
\hline & & 26 & L & 52 weeks PP & $58^{2}$ & \\
\hline \multirow[t]{2}{*}{72} & France & 306 & $\bar{L}$ & 1 & $50^{2}$ & $50-80^{1}$ \\
\hline & & 224 & L & 3 & $54^{2}$ & \\
\hline \multirow[t]{3}{*}{39,40} & Ireland & 38 & L & 1 & $135^{2}$ & $70^{2}$ \\
\hline & & 38 & $\bar{L}$ & 2 & $125^{2}$ & \\
\hline & & 38 & L & 3 & $122^{2}$ & \\
\hline 53 & Italy & 67 & $\mathrm{C}$ & 1,2 & $74^{3}$ & \\
\hline 31 & Italy & 18 & $\mathrm{C}$ & 3 & $50^{1}$ & \\
\hline 54,73 & Italy & 10 & $\mathrm{~L}$ & $1,2,3$ & $33^{1}$ & $46^{1}$ \\
\hline \multirow[t]{2}{*}{51} & Germany & 70 & L & 1 & $55^{3}$ & \\
\hline & & 70 & L & 11 days PP & $50^{3}$ & \\
\hline 46 & Germany & 109 & $\bar{C}$ & $1,2,3$ & $181^{3}$ & \\
\hline 49 & Hungary & 119 & $\mathrm{C}$ & $1,2,3$ & $57^{3}$ & \\
\hline 74 & New Zealand & 35 & $\mathrm{~L}$ & $1,2,3$ and $3,6,12$ months PP & $24-52^{1}$ & $24-47^{1}$ \\
\hline \multirow[t]{2}{*}{75} & Nepal & 1021 & $\mathrm{C} / \mathrm{L}$ & $1,2,3$ & $96^{1}$ & \\
\hline & & 1028 & $\mathrm{C} / \mathrm{L}$ & 13 weeks PP & $61^{1}$ & \\
\hline \multirow[t]{4}{*}{76} & Sudan & 47 & $\mathrm{~L}$ & 3 & $38^{2}$ & $76^{2}$ \\
\hline & & 47 & L & 3 months PP & $51^{2}$ & \\
\hline & & 47 & $\mathrm{~L}$ & 6 months PP & $30^{2}$ & \\
\hline & & 47 & L & 9 months PP & $63^{2}$ & \\
\hline 77 & Turkey & 80 & L & $1,2,3$ & $91^{1}$ & $85^{1}$ \\
\hline
\end{tabular}

${ }^{1} \mu \mathrm{g} \mathrm{day}^{-1} ;{ }^{2} \mu \mathrm{gl}^{-1} ;{ }^{3} \mu \mathrm{g} \mathrm{g}^{-1}$ creatinine.

and the free $\mathrm{T}_{4}$ concentration was significantly higher, than in unsupplemented women ${ }^{44}$. Although the maternal TSH concentration was lower in the supplement group, the cord TSH concentration was $27 \%$ higher in the supplement group ${ }^{50}$, suggesting that in iodine-deficient areas, the foetal thyroid gland may be particularly sensitive to the inhibitory effect of iodine. 
Table 3 Changes in thyroid size measured by ultrasound during pregnancy in iodine-sufficient and -deficient countries.

\begin{tabular}{|c|c|c|c|c|}
\hline Reference & $\begin{array}{l}\text { lodine status } \\
\text { Country }\end{array}$ & $n$ & $\begin{array}{l}\text { Trimester }(\mathrm{T}) \text { of pregnancy } \\
\text { or time post-partum (PP) }\end{array}$ & Change in thyroid size \\
\hline & lodine sufficient & & & \\
\hline 78 & Finland & $7-21$ & 1,2,3 T & No or small increase during pregnancy \\
\hline 79 & Netherlands & 10 & Before pregnancy, 1,2,3 T & No increase during pregnancy \\
\hline 80 & $\begin{array}{l}\text { USA } \\
\text { lodine deficient }\end{array}$ & 16 & $3 \mathrm{~T}$ and 6 months PP & $13 \%$ decrease after parturition \\
\hline 71 & Belgium & $33-172$ & 1,2,3 T and 6 months PP & $18 \%$ increase during pregnancy \\
\hline 10 & Belgium & 60 & $1,3 \mathrm{~T}$ & $30 \%$ increase during pregnancy \\
\hline 81 & Denmark & 20 & 2,3 T and 3,6,12 months PP & $20 \%$ increase during pregnancy \\
\hline 9 & Denmark & $24-26$ & $2,3 \mathrm{~T}$ and 3,6 months PP & $31 \%$ increase during pregnancy \\
\hline 82 & Ireland & $14-95$ & $1,2,3 \mathrm{~T}$ and 6,12 months PP & $15 \%$ increase during pregnancy \\
\hline 31 & Italy & 18 & $1,3 \mathrm{~T}$ & $16 \%$ increase during pregnancy \\
\hline
\end{tabular}

Table 4 shows results from six randomised, controlled trials of iodine supplementation involving 450 pregnant European women with mild-to-moderate ID.

Romano et al. ${ }^{31}$ gave $120-180 \mu \mathrm{g}$ iodine as iodised salt daily or gave a placebo control beginning in the first trimester to healthy pregnant women $(n=35$, median UI concentrations in the two groups 31 or $37 \mu \mathrm{gl}^{-1}$ ). In the group treated with iodine, the median UI concentration increased threefold and thyroid volume did not change ${ }^{31}$. In the controls, there was no change in the UI concentration, and had a 16\% increase in thyroid volume $^{31}$. Treatment had no effect on the maternal TSH concentration.

Pedersen et al. ${ }^{9}$ randomised 54 pregnant women to receive either $200 \mu \mathrm{g}$ iodine per day as a solution of potassium iodide or no supplement from 17 weeks of pregnancy to full term. The median UI concentration increased from 55 to $90-110 \mu \mathrm{gl}^{-1}$ in the treated group. The thyroid volume of women increased $16 \%$ in the treated group compared with $30 \%$ in the controls? The concentration of $\mathrm{Tg}$ and $\mathrm{TSH}$ in women, and the concentration of cord $\mathrm{Tg}$, were significantly lower in the treated group than in the controls? ${ }^{9}$. No significant differences were found between groups in terms of the concentration of $\mathrm{T}_{4}, \mathrm{~T}_{3}$ and $\mathrm{fT}_{4}$ in maternal or cord blood 9 .

Table 4 Randomised, controlled trials of iodine supplementation during pregnancy in mild-to-moderate iodine-deficient countries of Europe and the urinary iodine concentration before and after treatment.

\begin{tabular}{lccr}
\hline & \multicolumn{2}{c}{ Urinary iodine concentration } \\
\cline { 3 - 4 } Reference & $\begin{array}{c}\text { lodine dose } \\
\left(\mu \text { day }^{-1}\right)\end{array}$ & $\begin{array}{c}\text { Before } \\
\text { treatment }\end{array}$ & After treatment \\
\hline 53 & 50 & $65^{1}$ & $128^{1}$ \\
10 & 100 & $36^{2}$ & $80-90^{2}$ \\
31 & $120-180$ & $37^{3}$ & $100^{3}$ \\
52 & 150 & $50^{2}$ & $105^{2}$ \\
9 & 200 & $55^{2}$ & $90-110^{2}$ \\
53 & 200 & $91^{1}$ & $230^{1}$ \\
51 & 230 & $53^{1}$ & $104^{1}$ \\
\hline
\end{tabular}

${ }^{1} \mu \mathrm{g} \mathrm{g}^{-1} \mathrm{cr}_{\text {.; }}{ }^{2} \mu \mathrm{gl}^{-1} ;{ }^{3} \mu \mathrm{g} \mathrm{day}^{-1}$.
In a double-blind, placebo-controlled trial, Glinoer et $a l .{ }^{10}$ supplemented 120 pregnant women who had a median UI concentration of $36 \mu \mathrm{gl}^{-1}$ and biochemical criteria of excess thyroid stimulation, with $100 \mu \mathrm{g}$ iodine per day or gave a placebo control from around 14 weeks of pregnancy to full term. The treatment had no significant effect on the concentration of maternal or cord $\mathrm{T}_{3}, \mathrm{fT}_{4}$ and the $\mathrm{T}_{3} / \mathrm{T}_{4}$ ratio $^{10}$. The treated women had a significantly higher UI concentration, a smaller thyroid volume and a lower concentration of TSH and Tg when compared with controls $^{10}$. The newborn children of the treated group also had significantly higher UI concentration, a smaller thyroid volume and a lower Tg concentrations when compared with controls ${ }^{10}$. There was a $14 \%$ increase in the cord serum TSH concentration in the treated group, but it was not statistically significant.

Liesenkötter et $a l .^{51}$ reported a quasi-randomised, controlled trial of $230 \mu \mathrm{g}$ iodine per day given from the eleventh week of pregnancy to full term in 108 pregnant women with a median UI concentration of $53 \mu \mathrm{gg}^{-1} \mathrm{cr}$. and a goitre rate of $42.5 \%$. The median UI concentration increased to $104 \mu \mathrm{gg}^{-1} \mathrm{cr}$. in the treated group, and the median thyroid volume was significantly lower in the newborns of the treated women compared with controls $(0.7 \text { vs. } 1.5 \mathrm{ml} \text {, respectively })^{51}$. Treatment had no significant effect on the concentration of maternal $\mathrm{TSH}, \mathrm{T}_{3}, \mathrm{~T}_{4}, \mathrm{Tg}$ or on the thyroid volume, and had no effect on the concentration of TSH in the newborn ${ }^{51}$

In a placebo-controlled, double-blind trial, Nohr et al. ${ }^{52}$ gave to 66 pregnant women who had antibodies to antithyroid peroxidase (TPO-Ab) a multi-nutrient supplement containing $150 \mu \mathrm{g}$ iodine per day or a placebo control from the eleventh week of pregnancy to full term. The median UI concentration was significantly higher in the treated women at full term than in the controls, but there were no differences in the concentration of maternal TSH, $\mathrm{fT}_{4}$ or $\mathrm{Tg}$ between groups ${ }^{52}$. There was no difference in the prevalence of anti-thyroglobulin antibodies (Tg-Ab) or TPO-Ab, and no differences between groups in the prevalence or severity of post-partum thyroid dysfunction (PPTD), defined as an abnormal TSH concentration in the 
post-partum period. However, 12/20 (60\%) treated women developed PPTD compared with 11/24 (46\%) controls, and failure to detect a significant difference in the prevalence of PPTD may have been due to a type II error.

In a prospective, randomised, open-label trial, Antonangeli et $a l^{53}$ supplemented 67 pregnant women who had a median UI concentration of $74 \mu \mathrm{g} \mathrm{g}^{-1} \mathrm{cr}$. with 50 or $200 \mu \mathrm{g}$ iodine per day from 18-26 weeks of pregnancy to 29-33 weeks. The median UI concentration was significantly higher in group given $200 \mu \mathrm{g}$ iodine per day than in the group given $50 \mu \mathrm{g}$ iodine per day (230 vs. $128 \mu \mathrm{gg}^{-1}$ cr.). ${ }^{53}$ However, there were no differences between groups in the concentration of maternal $\mathrm{fT}_{4}, \mathrm{fT}_{3}$, TSH and $\mathrm{Tg}$ or in thyroid volume, and no differences in the prevalence of $\mathrm{TPO}-\mathrm{Ab}, \mathrm{Tg}-\mathrm{Ab}$ or PPTD.

In summary, in all of these trials, iodine supplements significantly increased the maternal UI concentration. The doses of iodine varied between 50 and $230 \mu \mathrm{gday}^{-1}$, and the data indicate no clear doseresponse relationship for the concentration of UI, TSH, $\mathrm{Tg}$, thyroid hormones or in terms of thyroid volume. Iodine supplements during pregnancy generally appear to be safe; there was no increase in the trials the prevalence of thyroid autoimmunity in mothers, or in the prevalence or severity of PPTD. However, the sample sizes were small and more data, particularly from TPO$\mathrm{Ab}+$ women, would be valuable. In three of the five trials that measured the thyroid volume of mothers, supplementation was associated with a significantly reduced thyroid size. The studies also suggest that an increase in newborn thyroid volume and the concentration of $\mathrm{Tg}$ can be prevented or minimised by iodine supplementation. Although less consistent, the data also suggest that the concentration of maternal TSH is generally lower (within the normal reference range) with supplementation. Supplementation has little or no impact on the concentration of total or free thyroid hormones in mothers and newborn children. There are no clinical data on the effect of supplementation on birth weight or prematurity, and no data on long-term outcomes, such as maternal goitre, thyroid autoimmunity or child development.

\section{Iodine intakes during lactation and urinary iodine and breast milk iodine concentrations}

Since the mammary gland is able to concentrate iodine, the iodine supply to the newborn via the breast milk may be maintained even in the face of a maternal $\mathrm{ID}^{54,55}$. This may help explain why, in areas where there is an ID, BMIC is often greater than expected based on the UI concentration of lactating mothers ${ }^{55,56}$. The BMIC is strongly influenced by the mothers' iodine intake ${ }^{58}$.
In the USA, Gushurst et $a l .{ }^{57}$ found that the median BMIC in women who consumed uniodised salt was $113 \mu \mathrm{gl}^{-1}$, while the median concentrations in women who consumed low or high amounts of iodised salt were 143 or $270 \mu \mathrm{g} \mathrm{l}^{-1}$, respectively.

Several studies have compared the BMIC before and after supplementation with iodised oil or potassium iodide, or with untreated controls.

Pretell et al. ${ }^{59}$ injected women with $950 \mathrm{mg}$ iodine as iodised oil. The median BMIC at 18-36 months postpartum was $70 \mu \mathrm{gl}^{-1}$ compared with $2 \mu \mathrm{gl}^{-1}$ in mothers not receiving treatment.

In Algeria, Chaouki and Benmiloud ${ }^{60}$ gave $240 \mathrm{mg}$ iodine as oral iodised oil either 1-3 months before pregnancy or in the first or third trimester. At delivery and 6 month post-partum, the mean BMIC ranged from 520 to $559 \mu \mathrm{gl}^{-1}$ and from 307 to $346 \mu \mathrm{gl}^{-1}$, compared with 307 and $260 \mu \mathrm{gl}^{-1}$ in untreated women.

In 147 Danish mothers, the median BMIC on the fifth day post-partum was significantly higher $\left(57 \mu \mathrm{gl}^{-1}\right)$ in those receiving supplementation with $150 \mu \mathrm{g}_{\text {day }}{ }^{-1}$ of oral iodine, compared with women who were not supplemented $\left(34 \mu \mathrm{gl}^{-1}\right)^{61}$.

In Germany, 60 mothers who received $200 \mu \mathrm{g} \mathrm{day}^{-1}$ of oral iodine had a significantly higher mean iodine concentration in breast milk $\left(76 \mu \mathrm{gl}^{-1}\right)$ than untreated controls $\left(55 \mu \mathrm{gl}^{-1}\right)^{62}$.

Although increasing the iodine intake of iodinesufficient women can further increase $\mathrm{BMIC}^{57}$, an iodine intake by an infant that is greater than requirements will simply be excreted in the urine. Thus, iodine requirements during lactation should be based on infant balance studies rather than on the measured but variable amount of iodine excreted in breast milk by women in iodine-sufficient countries. Based on the balance studies of Delange et al. ${ }^{30}$, the full-term infant's requirement for iodine is about $90 \mu \mathrm{g} \mathrm{day}^{-1}$, and this is the intake recommended by the WHO, UNICEF and the ICCIDD ${ }^{15}$. Based on a mean breast milk volume of $0.781 \mathrm{day}^{-1}$ in the first 6 months of infancy ${ }^{25}$, and assuming that $95 \%$ of the iodine in breast milk is absorbed, a BMIC of $\geq 120 \mu \mathrm{g}^{-1}$ should cover the infant's iodine requirement of $90 \mu \mathrm{g} \mathrm{day}^{-1}$ until weaning foods are begun. Most infants begin weaning by the second half of the first year of life, and some of the iodine requirement during that period will be met from weaning foods. Semba and Delange ${ }^{58}$ proposed that a potential indicator of iodine status in a population could be the proportion of lactating women whose BMIC is $\geq 100 \mu \mathrm{gl}^{-1}$.

Table 5 shows the BMICs of women living in areas where people are iodine sufficient or have mild-tosevere ID. Among the iodine-sufficient countries, the BMICs of women in Switzerland and Sweden are less than the concentration required to meet an infant's needs $\left(100-120 \mu \mathrm{gl}^{-1}\right)$, while they are at, or above, 
Table 5 The mean or median breast milk iodine concentration of women in iodine-sufficient and -deficient countries.

\begin{tabular}{|c|c|c|}
\hline $\begin{array}{l}\text { lodine sufficient } \\
\text { Reference }\end{array}$ & Country & $\mu \mathrm{gI}^{-1}$ \\
\hline 83 & Finland & $25-53$ \\
\hline 84 & Japan & 661 \\
\hline 85 & Japan & $33-385$ \\
\hline 86 & New Zealand & $98-247$ \\
\hline 87 & The Netherlands & 10 \\
\hline 88 & Saudi Arabia & $136-198$ \\
\hline 89 & Saudi Arabia & $149-204$ \\
\hline 90 & South Korea & 892 \\
\hline 91 & Sweden & 93 \\
\hline 92 & Sweden & 56 \\
\hline 93 & Switzerland & 78 \\
\hline 57 & USA & 60 \\
\hline 94 & USA & $113-270$ \\
\hline 95 & USA & 142 \\
\hline \multicolumn{3}{|l|}{ lodine deficient } \\
\hline 96 & Australia & 50 \\
\hline 97 & Belgium & 54 \\
\hline 91 & Belgium & 95 \\
\hline 98 & Ethiopia & $5-16$ \\
\hline 99 & France & 74 \\
\hline 100 & France & 70 \\
\hline 101 & France & 82 \\
\hline 102 & Germany & 7 \\
\hline 103 & Germany & 55 \\
\hline 91 & Germany & 25 \\
\hline 104 & Germany & 93 \\
\hline 105 & Germany & $18-25$ \\
\hline 106 & Germany & $30-34$ \\
\hline 92 & Guatemala & 60 \\
\hline 92 & Hungary & 64 \\
\hline 107 & Italy & 150 \\
\hline 108 & Italy & 59 \\
\hline 54 & Italy & $33-43$ \\
\hline 109 & Morocco & $27-40$ \\
\hline 110 & Niger & 40 \\
\hline 92 & Nigeria & 62 \\
\hline 92 & Philippines & 57 \\
\hline 111 & Reunion & $18-54$ \\
\hline 112 & Slovakia & $81-89$ \\
\hline 113 & Spain & 100 \\
\hline 114 & Spain & 109 \\
\hline 115 & Spain & $77-100$ \\
\hline 116 & Thailand & $45-68$ \\
\hline 117 & Turkey & 109 \\
\hline 56 & Turkey & 73 \\
\hline 92 & Zaire & 15 \\
\hline
\end{tabular}

this concentration in the Netherlands, the USA and Japan.

Although the requirement for iodine of a mother is large at 200-290 $\mathrm{g} \mathrm{day}^{-1}$, after accounting for iodine losses in breast milk, the median UI concentration of lactating women that indicates adequate iodine nutrition should be similar to that of non-pregnant, non-lactating women, i.e. $100-199 \mu \mathrm{g}$ per $\mathrm{l}^{15}$. Table 6 shows the UI concentrations reported from studies of lactating women in iodine-sufficient and-deficient countries. There are few data, the numbers of women in most studies are small, and breast-feeding status was often not clearly documented. The studies generally report a median UI concentration in lactating women that is similar to the general population, but almost all reports are from
Table 6 Urinary iodine concentration ${ }^{1-3}$ in lactating women and in the general population or in non-lactating controls in countries of different iodine status.

\begin{tabular}{|c|c|c|c|c|c|}
\hline Reference & $\begin{array}{l}\text { Iodine status } \\
\text { Country }\end{array}$ & $n$ & $\begin{array}{c}\text { Time } \\
\text { post-partum }\end{array}$ & $\begin{array}{l}\text { Urinary } \\
\text { iodine }\end{array}$ & $\begin{array}{l}\text { General } \\
\text { population } \\
\text { or controls }\end{array}$ \\
\hline & lodine excess & & & & \\
\hline 37 & $\begin{array}{l}\text { Chile } \\
\text { lodine sufficie }\end{array}$ & $\mathrm{nt}^{19}$ & 3 months & $459^{1}$ & \\
\hline 41 & Singapore & 230 & $\begin{array}{c}6 \text { weeks } \\
3 \text { months }\end{array}$ & $\begin{array}{l}105^{2} \\
104^{2}\end{array}$ & $98^{2}$ \\
\hline & lodine deficien & & & & \\
\hline 9 & Denmark & $\begin{array}{l}26 \\
26 \\
26\end{array}$ & $\begin{array}{c}1 \text { week } \\
26 \text { weeks } \\
52 \text { weeks }\end{array}$ & $\begin{array}{l}30^{2} \\
50^{2} \\
58^{2}\end{array}$ & $50^{1}$ \\
\hline 39 & Ireland & 108 & 6 weeks & $70^{2}$ & $70^{2}$ \\
\hline 51 & Germany & 70 & 11 days & $50^{3}$ & \\
\hline 74 & New Zealand & 35 & $3,6,12$ months & $24-52^{1}$ & $24-47^{1}$ \\
\hline 75 & Nepal & 1028 & 13 weeks & $61^{1}$ & \\
\hline 76 & Sudan & 47 & 3-9 months & $30-63^{2}$ & $76^{2}$ \\
\hline 56 & Turkey & 70 & 5 days & $30^{2}$ & \\
\hline
\end{tabular}

iodine-deficient countries, and show median UI concentrations $<100 \mu \mathrm{gl}^{-1}$.

\section{Iodine intakes during infancy}

During infancy, the mean volume of breast milk consumed is about $0.781 \mathrm{day}^{-1}$ over the first $0-6$ months $^{25}$ and some $60-65 \%$ of ingested water is excreted by the kidney ${ }^{63}$. Although there is a large day-to-day variation, the volume of urine daily in early infancy is estimated to be 30$55 \mathrm{ml} \mathrm{kg}^{-1}$ body weight ${ }^{63-65}$ and the reference body weight for a child aged $0-6$ months is $7 \mathrm{~kg}$ and for a child aged 6-12 months is $9 \mathrm{~kg}^{25}$. Based on these data, the volume of urine is estimated to be $0.4-0.51$ day $^{-1}$ in early infancy. Therefore, considering the requirement for iodine of $90 \mu \mathrm{g}$ per day ${ }^{15}$, the median UI concentration indicating optimal iodine nutrition in infancy is estimated to be in the range of $\geq 180-220 \mu \mathrm{g}$ per $\mathrm{I}^{26}$.

Delange et $a{ }^{66}$ supplemented healthy infants and children aged 6 months to 3 years in Belgium who had a median UI concentration at baseline of $101 \mu \mathrm{gl}^{-1}$, with an dose of $90 \mu \mathrm{g} \mathrm{day}^{-1}$ of iodine. After about 30 days of supplementation, the geometric mean UI concentration was beginning to plateau at $220-240 \mu \mathrm{gl}^{-1}$.

Table 7 shows the median UI in full-term newborns in countries with iodine sufficiency and varying degrees of ID. In general, among the iodine-sufficient countries, the median UI concentration varies from 96 to $167 \mu \mathrm{gl}^{-1}$, well below the estimated median UI concentration of $\geq 180-220 \mu \mathrm{gl}^{-1}$ that indicates an adequate iodine intake. More data are clearly needed, but the evidence available suggests that the iodine intake of many infants, even in countries designated as iodine sufficient, may be suboptimal. 
Table 7 The median urinary iodine concentration of full-term infants in iodine-sufficient and -deficient countries $\left({ }^{1}=\right.$ Mean $)$.

\begin{tabular}{|c|c|c|c|}
\hline Reference & $\begin{array}{l}\text { Iodine status } \\
\text { Country }\end{array}$ & $n$ & $\mu \mathrm{gl}^{-1}$ \\
\hline & lodine sufficient & & \\
\hline 119 & Canada & 81 & 148 \\
\hline 119 & The Netherlands & 64 & 162 \\
\hline 87 & The Netherlands & 36 & $150^{1}$ \\
\hline 119 & Sweden & 39 & 112 \\
\hline 105 & Sweden & 61 & 96 \\
\hline 118 & $\begin{array}{l}\text { USA } \\
\text { lodine deficient }\end{array}$ & 50 & 921 \\
\hline 118 & Belgium & 103 & 35 \\
\hline 119 & Belgium & 196 & 48 \\
\hline 120 & Belgium & 90 & 86 \\
\hline 121 & Czech Republic & 50 & 79 \\
\hline 119 & France & 82 & 58 \\
\hline 119 & France & 37 & 29 \\
\hline 105 & Germany & 461 & $12-29$ \\
\hline 119 & Germany & 87 & 28 \\
\hline 122 & Germany & 177 & 31 \\
\hline 122 & Germany & 213 & 44 \\
\hline 123 & Germany & 22 & 50 \\
\hline 124 & Germany & 32 & $95^{1}$ \\
\hline 119 & Germany & 81 & 15 \\
\hline 119 & Germany & 39 & 13 \\
\hline 119 & Germany & 39 & 11 \\
\hline 125 & Hungary & 209 & $35-75$ \\
\hline 126 & Ireland & - & $100^{1}$ \\
\hline 119 & Italy & 114 & 47 \\
\hline 119 & Italy & 14 & 71 \\
\hline 127 & Italy & 195 & 56 \\
\hline 128 & Italy & 9 & 67 \\
\hline 56 & Turkey & 70 & 24 \\
\hline
\end{tabular}

\section{References}

1 Pharoah POD, Buttfield IH, Hetzel BS. Neurological damage to the fetus with severe iodine deficiency during pregnancy. Lancet 1971; i: 308-10.

2 Pharoah POD. The clinical pattern of endemic cretinism in Papua New Guinea. Journal of Experimental Medicine and Biology 1972; 30: 71-82.

3 Chaouki ML, Benmiloud M. Prevention of iodine deficiency disorders by oral administration of lipiodol during pregnancy. European Journal of Endocrinology 1994; 130: $547-51$.

4 Cobra C, Muhilal, Rusmil K, Rustama D, Djatnika, Suwardi SS, Permaesih D, Muherdiyantiningsih M, Martuti S, Semba RD. Infant survival is improved by oral iodine supplementation. Journal of Nutrition 1997; 127: $574-8$.

5 Dillon JC, Milliez J. Reproductive failure in women living in iodine deficient areas of West Africa. British Journal of Obstetrics and Gynaecology 2000; 107: 631-6.

6 Fierro-Benitez R, Cazar R, Stanbury JB, Rodriguez P, Garces F, Fierro-Renoy F, Estrella E. Effects on school children of prophylaxis of mothers with iodized oil in an area of iodine deficiency. Journal of Endocrinological Investigation 1988; 11: 327-35.

7 Pharoah POD, Connolly KJ. A controlled trial of iodinated oil for the prevention of endemic cretinism: a long-term follow-up. International Journal of Epidemiology 1987; 16: $68-73$.

8 Azizi F, Kalani H, Kimiagar M, Ghazi A, Sarshar A, Nafarabadi M, Rahbar N, Noohi S, Mohajer M, Yassai M. Physical, neuromotor and intellectual impairment in non-cretinous schoolchildren with iodine deficiency.
International Journal of Vitamin and Nutrition Research 1995; 65: 199-205.

9 Pedersen KM, Laurberg P, Iversen E, Knudsen PR, Gregersen HE, Rasmussen OS, Larsen KR, Eriksen GM, Johannesen PL. Amelioration of some pregnancy-associated variations in thyroid function by iodine supplementation. Journal of Clinical Endocrinology and Metabolism 1993; 77: 1078-83.

10 Glinoer D, De Nayer P, Delange F, Lemone M, Toppet V, Spehl M, Grun JP, Kinthaert J, Lejeune B. A randomized trial for the treatment of mild iodine deficiency during pregnancy: maternal and neonatal effects. Journal of Clinical Endocrinology and Metabolism 1995; 80: 258-69.

11 Kung AWC, Lao TT, Low LCK, Pang RWC, Robinson JD. Iodine insufficiency and neonatal hyperthyrotropinemia in Hong Kong. Clinical Endocrinology 1997; 46: 315-9.

12 Delange F, Bourdoux P, Chanoine JP, Ermans AM. Physiopathology of iodine nutrition during pregnancy, lactation, and early postnatal life. In: Berger $\mathrm{H}$, ed. Vitamins and Minerals in Pregnancy and Lactation. Nestlé Nutrition Workshop Series, Vol. 16. New York: Raven Press, 1988.

13 Glinoer D, Delange F. The potential repercussions of maternal, fetal and neonatal hypothyroxinemia on the progeny. Thyroid 2000; 10: 871-87.

14 Bleichrodt N, Born MP. A metaanalysis of research on iodine and its relationship to cognitive development. In: Stanbury JB, ed. The Damaged Brain of Iodine Deficiency. New York: Cognizant Communication, 1994; 195-200.

15 WHO, UNICEF, and ICCIDD. Assessment of the Iodine Deficiency Disorders and Monitoring their Elimination. WHO/NHD/01.1 World Health Organization, Geneva, 2001.

16 Fisher DA, Oddie TH. Thyroidal radioiodine clearance and thyroid iodine accumulation: Contrast between random daily variation and population data. Journal of Clinical Endocrinology and Metabolism 1969; 29: 111-5.

17 Fisher DA, Oddie TH. Thyroid iodine content and turnover in euthyroid subjects: validity of estimation of thyroid iodine accumulation from short term clearance studies. Journal of Clinical Endocrinology and Metabolism 1969; 29: $721-7$.

18 Oddie TH, Fisher DA, Long JM. Factors affecting the estimation of iodine entering the normal thyroid gland using short-term clearance studies. Journal of Clinical Endocrinology and Metabolism 1964; 24: 924-33.

19 Dworkin HJ, Jacquez JA, Beierwaltes WH. Relationship of iodine ingestion to iodine excretion in pregnancy. Journal of Clinical Endocrinology and Metabolism 1966; 26: 1329-42.

20 Harrison MT. Iodine balance in man. Postgraduate Medical Journal 1968; 44: 69-71.

21 Harrison MT, Harden R, Alexander WD, Wayne E. Iodine balance studies in patients with normal and abnormal thyroid function. Journal of Clinical Endocrinology 1965; 25: $1077-84$

22 Malamos B, Koutras DA, Marketos SG, Rigopoulos GA, Yataganas XA, Binopoulos D, Sfontouris J, Pharmakiotis AD, Vought RL, London WT. Endemic goiter in Greece: an iodine balance study in the field. Journal of Clinical Endocrinology and Metabolism 1967; 27: 1372-80.

23 Vought RL, London WT. Iodine intake, excretion and thyroidal accumulation in healthy subjects. Journal of Clinical Endocrinology and Metabolism 1967; 27: 913-9.

24 Nath SK, Moinier B, Thuillier F, Rongier M, Desjeux JF. Urinary excretion of iodide and fluoride from supplemented food grade salt. International Journal of Vitamin and Nutrition Research 1992; 62: 66-72.

25 Institute of Medicine, Academy of Sciences, USA. Dietary Reference Intakes for Vitamin A, Vitamin K, Arsenic, 
Boron, Chromium, Copper, Iodine, Iron, Manganese, Molybdenum, Nickel, Silicon, Vanadium and Zinc. Washington DC: National Academy Press, 2001.

26 Delange F. Optimal iodine nutrition during pregnancy, lactation and the neonatal period. International Journal of Endocrinology and Metabolism 2004; 2: 1-12.

27 Glinoer $D$. The regulation of thyroid function in pregnancy: pathways of endocrine adaptation from physiology to pathology. Endocrine Reviews 1997; 18: 404-33.

28 Delange F. Iodine nutrition and congenital hypothyroidism. In: Delange F, Fisher DA, Glinoer D, eds. Research in Congential Hypothyroidism. New York: Plenum Press, 1989.

29 Delange F, Ermans AM. Iodine deficiency. In: Braverman LE, Utiger RD, eds. Werner and Ingbar's the Thyroid: A Fundamental and Clinical Text. 6 ed. Philadelphia: JD Lippincott, 1991.

30 Delange F, Bourdoux P, Vo Thi LD, Ermans AM, Senterre J. Negative iodine balance in preterm infants. Annals of Endocrinology 1984; 45: 77.

31 Romano R, Jannini EA, Pepe M, Grimaldi A, Olivieri M, Spennati P, Cappa F, D'Armiento M. The effects of iodoprophylaxis on thyroid size during pregnancy. American Journal of Obsterics and Gynecology 1991; 164: $482-5$.

32 WHO Secretariat on behalf of the participants to the Consultation. Prevention and control of iodine deficiency in pregnant and lactating women and in children less than 2-years-old: conclusions and recommendations of the Technical Consultation. Public Health Nutrition 2007; 10(3A).

33 Hollowell JG, Staehling NW, Hannon WH, Flanders DW, Gunter EW, Maberly GF, Braverman LE, Pino S, Miller DT, Garbe P. Iodine nutrition in the United States. Trends and public health implications: iodine excretion data from National Health and Nutrition Examination Surveys I and III (1971-1974 and 1988-1994). Journal of Clinical Endocrinology and Metabolism 1998; 83: 3401-8.

34 National Research Councl. Subcommittee on the Tenth Edition of the RDAs. Recommended Dietary Allowances. 10th ed. Washington, D.C., National Academy Press, 1989.

35 Mattsson S, Lindstrom S. Diuresis and voiding pattern in healthy schoolchildren. British Journal of Urology 1995; 76: 783-9.

36 Larsson G, Victor A. Micturition patterns in a healthy female population, studied with a frequency/volume chart. Scandinavian Journal of Urology and Nephrology 1988; 114: $53-7$.

37 Dafnis E, Sabatini S. The effect of pregnancy on renal function: physiology and pathophysiology. American Journal of Medical Science 1992; 303: 184-205.

38 Aboul-Khair SA, Crooks J, Turnbull AC, Hytten FE. The physiological changes in thyroid function during pregnancy. Clinical Science 1964; 27: 195-207.

39 Liberman CS, Pino SC, Fang SL, Braverman LE, Emerson $\mathrm{CH}$. Circulating iodide concentrations during and after pregnancy. Journal of Clinical Endocrinology and Metabolism 1998; 83: 3545-9.

40 Bourdoux P. Evaluation of the iodine intake: Problems of the iodine/creatinine ratio-comparison with iodine excretion and daily fluctuations of iodine concentration. Experimental Clinical Endocrinology and Diabetes 1998; 106: S17-S20.

41 Smyth PPA, Hetherton AMT, Smith DF, Radcliff M, O'Herlihy C. Maternal iodine status and thyroid volume during pregnancy: correlation with neonatal iodine intake. Journal of Clinical Endocrinology and Metabolism 1997; 82: $2840-3$.

42 Smyth PPA. Variation in iodine handling during normal pregnancy. Thyroid 1999; 9: 637-42.

43 Kung AWC, Lao TT, Chau MT, Tam SCF, Low LCK. Goitrogenesis during pregnancy and neonatal hypothyr- oxinaemia in a borderline iodine sufficient area. Clinical Endocrinology 2000; 53: 725-31.

44 Hess SY, Zimmermann MB, Torresani T, Bürgi H, Hurrell RF. Monitoring the adequacy of salt iodization in Switzerland: a national study of school children and pregnant women. European Journal of Clinical Nutrition 2001; 55: 162-6.

45 Zimmermann MB, Aeberli I, Bürgi H. A national study of the iodine nutrition of school children and pregnant women in Switzerland. American Journal of Clinical Nutrition 2005; 82: 388-92.

46 Berghout A, Wiersinga W. Thyroid size and thyroid function during pregnancy: an analysis. European Journal of Endocrinology 1998; 138: 536-42.

47 Zimmermann MB, Delange F. Iodine supplementation of pregnant women in Europe: a review and recommendations. European Journal of Clinical Nutrition 2004; 58: 979-84.

48 Buhling KJ, Schaff J, Bertram H, Hansen R, Muller C, Wascher C, Heinze T, Dudenhausen JW. Supply of iodine during pregnancy-an inventory in Berlin, Germany. Zeitschrift Geburtshilfe und Neonatologie 2003; 207: 12-16.

49 Nohr SB, Laurberg P, Borlum KG, Pedersen KM, Johannesen PL, Damm P, Fuglsang E, Johansen A. Iodine deficiency in pregnancy in Denmark: regional variations and frequency of individual iodine supplementation. Acta Obsterica et Gynecologica Scandinavica 1993; 72: 350-3.

50 German Ministry of Health. Iodine Monitoring 1996. In: Vol. 110, Series of the German Ministry of Health. Nomos, Baden-Baden, 1998 (in German).

51 Mezosi E, Molnar I, Jakab A, Balogh E, Karanyi Z, Pakozdy Z, Nagy P, Gyory F, Szabo J, Bajnok L, Leovey A, Kakuk G, Nagy EV. Prevalence of iodine deficiency and goitre during pregnancy in East Hungary. European Journal of Endocrinology 2000; 143: 479-83.

52 Nohr SB, Laurberg P. Opposite variations in maternal and neonatal thyroid function induced by iodine supplementation during pregnancy. Journal of Clinical Endocrinology and Metabolism 2000; 85: 623-7.

53 Liesenkötter KP, Göpel W, Bogner U, Stach B, Grüters A. Earliest prevention of endemic goiter by iodine supplementation during pregnancy. European Journal of Endocrinology 1996; 134: 443-8.

54 Nohr SB, Jorgensen A, Pedersen KM, Laurberg P. Postpartum thyroid dysfunction in pregnant thyroid peroxidase antibody-positive women living in an area with mild to moderate iodine deficiency: is iodine supplementation safe? Journal of Clinical Endocrinology and Metabolism 2000; 85: 3191-8.

55 Antonangeli L, Maccherini D, Cavaliere R, Di Giulio C, Reinhardt B, Pinchera A, Aghini-Lombardi F. Comparison of two different doses of iodide in the prevention of gestational goiter in marginal iodine deficiency: a longitudinal study. European Journal of Endocrinology 2002; 147: 29-34.

56 Vermiglio F, Lo Presti VP, Finocchiaro MD, Battiato S, Grasso L, Ardita FV, Mancuso A, Trimarchi F. Enhanced iodine concentration capacity by the mammary gland in iodine deficient lactating women of an endemic goiter region in Sicily. Journal of Endocrinological Investigation 1992; 15: 137-42.

57 Dorea JG. Iodine nutrition and breast feeding. Journal of Trace Elements in Medicine and Biology 2002; 16: 207-20.

58 Kurtoglu S, Akcakus M, Kocaoglu C, Gunes T, Budak N, Emre Atabek M, Karakucuk I, Delange F. Iodine status remains critical in mother and infant in Central Anatolia (Kayseri) of Turkey. European Journal of Nutrition 2004; 43: $297-303$.

59 Gushurst CA, Mueller JA, Green JA, Sedor F. Breast milk iodine: reassessment in the 1980s. Pediatrics 1984; 73: $354-7$. 
60 Semba RD, Delange F. Iodine in human milk: perspectives for human health. Nutrition Reviews 2001; 59: 269-78.

61 Pretell EA, Moncloa F, Salinas R, Kawano A, Guerra-Garcia R, Gutierrez L, Beteta L, Pretell J, Wan M. Prophylaxis and treatment of endemic goiter in Peru with iodized oil. Journal of Clinical Endocrinology and Metabolism 1969; 29: $1586-95$.

62 Chaouki ML, Benmiloud M. Prevention of iodine deficiency disorders by oral administration of Lipiodol during pregnancy. European Journal of Endocrinology 1994; 130: $547-51$.

63 Nohr SB, Laurberg P, Bortum KG, Pedersen KM, Johannesen PL, Damm P, Fuglsang E, Johansen A. Iodine status in neonates in Denmark: regional variations and dependency on maternal iodine supplementation. Acta Paediatrica 1994; 83: 578-82.

64 Seibold-Weiger K, Wollmann H, Rendl J, Ranke M, Speer C. Iodine concentration in the breast milk of mothers of premature infants. Zeitschrift Geburtshilfe und Neonatologie 1999; 203: 81-5.

65 Greenbaum LA. Pathophysiology of body fluids and fluid therapy. Maintenance and replacement therapy. In: Behrman RE, Kliegman RM, Jensen HB, eds. Nelson Textbook of Pediatrics. 17th ed. Philadelphia: Saunders, 2004; 242-5.

66 Thüroff JW, Schulte-Wissermann H. Pediatric Urology: Clinical Practice. Stuttgart: Thieme, 2000.

67 Travis LB. Disorders of water, electrolytes, and acid-base physiology. In: Rudolph AM, Hoffman JIE, Rudolph CD, eds. Rudolph's Pediatrics. 20th ed. Stamford, Connecticut Appleton \& Lange, 1996; 1319-21.

68 Fomon S. Iodine. In: Fomon S, ed. Nutrition of Normal Infants. St.Louis, Mosby-Year Book, 1993.

69 Delange F, Wolff P, Gnat D, Dramaix M, Pilchen M, Vertongen F. Iodine deficiency during infancy and early childhood in Belgium: does it pose a risk to brain development? European Journal of Pediatrics 2001; 160: 251-4.

70 Azizi F, Shaikholesmani R, Hedayati M, Mirmiran P, Malekafzali H, Kimiagar M. Sustainable control of iodine deficiency in Iran. Journal of Endocrinological Investigation 2002; 25: 409-13.

71 Elnagar B, Eltom A, Wide L, Gebre-Medhin M, Karlsson FA. Iodine status, thyroid function and pregnancy: study of Swedish and Sudanese women. European Journal of Nutrition 1998; 52: 351-5.

72 Brander L, Als C, Buess H, Haldimann F, Harder M, Hanggi W, Herrmann U, Lauber K, Niederer U, Zurcher T, Burgi U, Gerber H. Urinary iodine concentration during pregnancy in an area of unstable dietary iodine intake in Switzerland. Journal of Endocrinological Investigation 2003; 26: 389-96.

73 Soldin OP, Soldin SJ, Pezzullu JC. Urinary iodine percentile ranges in the United States. Clinica Chimica Acta 2003; 328: $185-90$

74 Glinoer D, de Nayer P, Bourdoux P, Lemone M, Robyn C, Van Steirteghem A, et al. Regulation of maternal thyroid during pregnancy. Journal of Clinical Endocrinology and Metabolism 1990; 71: 276-87.

75 Caron P, Hoff M, Bazzi S, Dufor A, Faure G, Ghandour I, Lauzu P, Lucas Y, Maraval D, Mignot F, Ressigeac P, Vertongen F, Grange V. Urinary iodine excretion during normal pregnancy in healthy women living in the Southwest of France: correlation with maternal thyroid parameters. Thyroid 1997; 7: 749-54.

76 Vermiglio F, Lo Presti VP, Castagna MG, Violi MA, Moleti M, Finocchiaro MD, Mattina F, Artemisia A, Trimarchi F. Increased risk of maternal thyroid failure with pregnancy progression in an iodine deficient area with major iodine deficiency disorders. Thyroid 1999; 9: 19-24.

77 Thomson CD, Packer MA, Butler JA, Duffield AJ, O'Donaghue KL, Whanger PD. Urinary selenium and iodine during pregnancy and lactation. Journal of Trace Elements in Medicine and Biology 2001; 14: 210-7.

78 Schulze KJ, West KP Jr, Gautschi LA, Dreyfuss ML, LeClerq SC, Dahal BR, Wu LS, Khatry SK. Seasonality in urinary and household salt iodine content among pregnant and lactating women of the plains of Nepal. European Journal of Clinical Nutrition 2003; 57: 969-76.

79 Eltom A, Eltom M, Elnagar B, Elbagir M, Gebre-Medhin M. Changes in iodine metabolism during late pregnancy and lactation: a longitudinal study among Sudanese women. European Journal of Clinical Nutrition 2000; 54: 429-33.

80 Mocan MZ, Erem C, Telatar M, Mocan H. Urinary iodine levels in pregnant women with and without goiter in the Eastern Black Sea of Turkey. Trace Elements and Electrolytes 1995; 12: 195-7.

81 Brander A, Kivisaari L. Ultrasonography of the thyroid during pregnancy. Journal of Clinical Ultrasound 1989; 17: 403-6.

82 Berghout A, Endert E, Ross A, Hogerzeil HV, Smits NJ, Wiersinga WM. Thyroid function and thyroid size in normal pregnant women living in an iodine replete area. Clinical Endocrinology (Oxford) 1994; 41: 375-9.

83 Nelson M, Wickus GG, Caplan RH, Beguin EA. Thyroid gland size in pregnancy. An ultrasound and clinical study. Journal of Reproductive Medicine 1987; 32: 888-90.

84 Rasmussen NG, Hornnes PJ, Hegedus L. Ultrasonographically determined thyroid size in pregnancy and post partum: the goitrogenic effect of pregnancy. American Journal of Obstetrics and Gynecology 1989; 160: 1216-20.

85 Smyth PPA, Hetherton AM, Ryan R, O'Herlihy C. Alterations in iodine status and thyroid volume during pregnancy. In: Beckers C, Reinwein D, eds. The Thyroid and Pregnancy. Stuttgart: Schattauer, 1991; 55-8.

86 Lahesmaa P, Vilkki P. The iodine content of human milk in Finland. Acta Paediatrica 1960; 49: 371

87 Yamamoto Y, Yonekubo A, Iida K, Takahashi S, Tsuchyia F. The composition of Japanese human milk. I. Micronutrient and mineral composition. Shonihoken-Kemkyu 1981; 40: 468

88 Chiba M, Ichikawa R. Secretion rate of dietary iodine into human milk. Journal of Radiation Research 1968; 9: 12-17.

89 Johnson LA, Ford HC, Doran J, Richardson VF. A survey of the iodide concentration of human milk. New Zealand Medical Journal 1990; 103: 393-4.

90 Bakker B, Vulsma T, de Randamie J, Achterhuis AM, Wiedij B, Oosting H, Glas C, de Vijlder JJ. A negative iodine balance is found in healthy neonates compared with neonates with thyroid agenesis. Journal of Endocrinology 1999; 161: 115-20.

91 Trabzuni DM, Ibrahim HS, Ewaidah EH. An assessment of iodine status of Saudi lactating mothers and its relation to iodine intake in Riyadh City. Ecology of Food and Nutrition 1998; 37: 297-307.

92 Younes B, Almeshad A, Alhakeem A, Alzamil F, Alsaleh S, Alattas O. Iodine level in breast milk of nursing mothers living in Riyadh City. Medical Science Research 1994; 22: 675-6.

93 Moon S, Kim J. Iodine content of human milk and dietary iodine intake of Korean lactating mothers. International Journal of Food Science and Nutrition 1999; 50: 165-71.

94 DeLange F. Iodine deficiency. In: Braverman LE, Utiger RD, eds. The Thyroid. New York: Lippincott Williams \& Wilkins, 2000; 295-316.

95 Parr RM, DeMayer EM, Iyengar VG, Byrne AR, Kirkbright GF, Schoch G, Niistro L, Pineda O, Vis HL, Hofvander Y, Omolulu A. Minor and trace elements in human milk from Guatemala, Hungary, Nigeria, Phillipines, Sweden and Zaire. Results from a WHO/IAEA Joint Project. Biological Trace Element Research 1991; 29: 51-75. 
96 Hoang-Truong T, Gerber H, Haenel AF, Burgi H. Iodine supply at various periods in life and ultrasonographic thyroid volume in school children in a region of Switzerland. Schweizerische Medizinische Wochenschrift 1997; 127: 715-21.

97 Man EB, Benotti J. Butanol-extractable iodine in human and bovine colostrum and milk. Clinical Chemistry 1969; 15: $1141-6$.

98 Bruhn JC, Franke AA. Iodine in human milk. Journal of Dairy Science 1983; 66: 1396-8.

99 Jansson L, Ivarsson S, Larsson I, Ekman R. Triiodothyronine and thyroxine in human milk. Acta Paediatrica Scandinavica 1983; 72: 703-5.

100 Beckers C, Augustijnen M-TH, Jaeken J, Devlieger H, Vanderschueren-Lodewyckx M, De Nayer PH, Eggermont E. Iodine intake of breast-fed versus bottle-fed healthy newborns and prematures. Annales d'Endocrinologie 1987; 48: $166-71$.

101 Cherinet A, Kelbessa U. Determinants of iodine deficiency in school children in different regions of Ethiopia. East African Medical Journal 2000; 77: 133-7.

102 Aquaron R. Iodine content of human breast milk and cow milk in France. IV Journeés Scientifiques Internationates du GERM, Paris, Editions INSERM,1989.

103 Texier F, Roque d'Orbcastel O, Etling N. Stable iodine level in human milk after pulmonary angiography. Presse Medicale 1983; 12: 769

104 Etling N, Gehin-Fouque F. Iodinated compounds and thyroxine binding to albumin in human breast milk. Pediatrics Research 1984; 18: 901-3.

105 Bauch K. Alimentary iodine deficiency in East Germany and its reflection in thyroid parameters following the initiation of struma prevention. Deutsche Zeitschrift fur Verdauungs- und Stoffwechselkrankheiten 1987; 47: 341-6.

106 Bohles H, Aschenbrenner M, Roth M, von Loewenich V, Ball F, Usadel KH. Development of thyroid gland volume during the first 3 months of life in breast-fed versus iodinesupplemented and iodine-free formula-fed infants. Clinical Investigation 1993; 71: 13-20.

107 Heidemann PH, Stubbe P, Thal H, Hellstrom R, Skanke N, Larsson A. Influence of iodine prophylaxis on thyroid function and iodine excretion in newborn infants and their mothers: comparison between Sweden and Germany. Acta Endocrinologica 1986; 3(Suppl. 274): 47-8.

108 Heidemann PH, Stubbe P, von Reuss K, Schurnbrand P, Larson A, von Petrykowski W. Iodine excretion and dietary iodine supply in newborn infants in iodine-deficient regions of West Germany. Deutsche Medizinische Wochenschrift 1984; 109: 773-8.

109 Wiechen A, Kock M. Routine determination of low iodine concentration in milk. Fresenius Zeitschrift Analytische Chemie 1984; 319: 569-72.

110 Chierici R, Saccomandi D, Vigi V. Dietary supplements for the lactating mother: influence on the trace element content of milk. Acta Paediatrica Supplement 1999; 88: 7-13.

111 Etling N, Padovani E, Fouque F, Tato L. First month variations in total iodine content of human breast milks. Early Human Development 1986; 13: 81-5.

112 Aquaron R, Zarrouck K, el Jarari M, Ababou R, Talibi A, Ardissone JP. Endemic goiter in Morocco (SkouraToundoute areas in the high Atlas). Journal of Endocrinological Investigation 1993; 16: 9-14.

113 Aquaron R, Aquaron C, Daouda H, Madi N, Roux F, Bisset JP. Study of two goitrous endemic areas in Niger: Belley-Koira and Tiguey-Tallawal. Annals of Endocrinology 1990; 51: 231-40.

114 Jaffiol C, Manderscheid JC, Rouard L, Dhondt JL, Arguillere S, Bourdoux P. Iodine deficiency in the Cirque of Salazie (Reunion Island). Analysis of nutritional factors and evaluation of its consequences. Bulletin de l'Academie Nationale de Medecine 1997; 181: 1795-810.

115 Tajtakova M, Capova J, Bires J, Sebokova E, Petrovicova J. Thyroid volume, urinary and milk iodine in mothers after delivery and their newborns in iodine-replete country. Endocrine Regulations 1999; 33: 9-15.

116 Ares S, Quero J, Duran S, Presas MJ, Herruzo R, Morreale de Escobar G. Iodine content of infant formulas and iodine intake of premature babies: high risk of iodine deficiency. Archives of Disease in Childhood Fetal and Neonatal Edition 1994; 71: F184-91.

117 Fernandez-Sanchez L, Szupnar J. Speciation analysis for iodine in milk by size-exclusion chromatography with inductively coupled plasma mass spectrometry (SECICPMS). Journal of Analytical Atomic Spectrometry 1999; 14: 1697-702.

118 Mallol J, Morreate de Escobar G, Escobar del Rey F. Thyroid hormone and iodine intakes of bottle-fed versus breast-fed babies. Endocrinologia 1984; 35: 12-20.

119 Pongpaew P, Supawan V, Tungtrongchitr R, Phonrat B, Vudhivai N, Chantaranipapong Y, Kitjaroentham A, Jintaridhi $\mathrm{P}$, Intarakhao $\mathrm{C}$, Mahaweerawat U, Saowakhontha S, Schelp FP. Urinary iodine excretion as a predictor of the iodine content of breast milk. Journal of the Medical Association of Thailand 1999; 82: 284-9.

120 Gokmen IG, Dagli G. Determination of iodine concentration in human-milk, cows milk and infant formula and estimation of daily iodine intake of infants. Analyst 1995; 120: $2005-8$.

121 Delange F, Dalhem A, Bourdoux P, Lagasse R, Glinoer D, Fisher DA, Walfish PG, Ermans AM. Increased risk of primary hypothyroidism in preterm infants. Journal of Pediatrics 1984; 105: 462-9.

122 Delange F, Heidemann P, Bourdoux P, Larsson A, Vigneri R, Klett M, Beckers C, Stubbe P. Regional variations of iodine nutrition and thyroid function during the neonatal period in Europe. Biology of the Neonate 1986; 49: 322-30.

123 Ciardelli R, Haumont D, Gnat D, Vertongen F, Delange F. The nutritional iodine supply of Belgian neonates is still insufficient. European Journal of Pediatrics 2002; 161: $519-23$.

124 Hnikova O, Hromadkova M, Wiererova O, Bilek R. Followup study of iodine status in neonates and their mothers in 2 regions of the Czech Republic after a 3-year intervention. Casopis Lekaru Ceskych 1999; 138: 272-5.

125 Grüters A, Liesenkötter KP, Willgerodt H. Persistence of differences in iodine status in newborns after the reunification of Berlin. New England Journal of Medicine 1995; 333: 1429.

126 Roth C, Meller J, Bobrzik S, Thal H, Becker W, Kulenkampff $\mathrm{D}$, Lakomek M, Zappel H. The iodine status of newborns. Deutsche Medizinische Wochenschrift 2001; 126: 321-5.

127 Klett M, Ohlig M, Manz F, Tröger J, Heinrich U. Effect of iodine supply on neonatal thyroid volume and TSH. Acta Paediatrica Supplement 1999; 432: 18-20.

128 Peter F, Muzsnai A, Bourdoux P. Changes of urinary iodine excretion of newborns over a period of twenty years. Journal of Endocrinological Investigation 2003; 26(S2): 39-42.

129 Barakat M, Carson D, Hetherton AM, Smyth P, Leslie H. Hypothyroidism secondary to topical iodine treatment in infants with spina bifida. Acta Paediatrica 1994; 83: 741-3.

130 Rapa A, Chiorboli E, Corbetta C, Sacco F, Bona G, Study AU. Urinary iodine excretion screening in newborns exposed to iodine-containing antiseptics. Hormone Research 1996; 46: 74.

131 Bona G, Chiorboli E, Rapa A, Weber G, Vigone MC, Chiumello G. Measurement of urinary iodine excretion to reveal iodine excess in neonatal transient hypothyroidism. Journal of Pediatric Endocrinology and Metabolism 1998; 11: $739-43$. 